\title{
Domination, Subsistence, and Interdependence: Tracing Resource Claim Networks across Iceland's Post-Reformation Landscape
}

\author{
Gísli Pálsson ${ }^{1}$ (D) \\ Published online: 27 July 2019 \\ (C) The Author(s) 2019
}

Keywords Landscape archaeology $\cdot$ Historical archaeology $\cdot$ Network analysis $\cdot$ Land use $\cdot$ Resource access $\cdot$ Iceland

Kong. Mayt. Tilsetter Commissarii á Islande, vid Arne Magnusson og Paall Jonsson Widalin, giörum hier med kunnigt, ad á medal annara erenda, sem hæhstnefnd Kongleg Maiestat ockur allra nádugast befalad hefur hier i lande ad utrietta, er ad samanntaka eina rigtuga og fullkomna jardabok yfer allt landed ... Pvi tilseigest hier med ollum og sierhvorum jardareigendum hier á lande, andlegum og veraldlegum, upp ad teikna allar sijnar jarder, med peirra dijrleika, landskulld og kugildum, item hiaaleigur og búder, par sem pær eru.

- Árni Magnússon, Embedsskrivelser, (1916: 20-21)

In the above passage, Árni Magnússon and Páll Vídalin declare their intention to produce 'the most perfect'land use survey of Iceland's early eighteenth century society. Their subsequent efforts can hardly be faulted. Over the next 13 years they travelled across the country gathering Iceland's community of farmers and recorded their accounts of farming practices, farm valuation, rent, livestock, quarrels over contested lands, nearby antiquities and a wealth of other information to compile the survey that would become known as Jarðabók Árna Magnússonar og Páls Vídalín (for a detailed account of the content see Pálsson 2018; Guðmundsson 1993). The descriptions not only detail the affordances of the farmsteads themselves, but also any claim that a farmstead had on the resources of other farms. These claims, called itök, suggest an agricultural society both highly interconnected and interdependent. The claims have not been explored at a scale that reveals the extent of this connectedness. In this paper I consider itök in their entirety as they were recorded in the early eighteenth century. Due to the complexity of these claim systems it is not my intention to examine

Gísli Pálsson

gisli.palsson@umu.se

1 Umeå University, Umeå, Sweden them diachronically at this stage, but Magnússon and Vídalin's highly detailed census in the early eighteenth century affords the best opportunity to study the breadth of these resource claims. I begin with a brief description followed by a characterisation of these claims. I conclude with with a discussion of their implications.

\section{Hin Rigtuga Og Fullkomna Jarðabók ${ }^{1}$}

The methodology of Jarðabók is outlined in a document signed by the two surveyors at Öxará, 18.7.1702 (Magnússon 1916: 21), and was to include information on the ownership, value, tithe, property tax, rental fees, livestock numbers, tenant farms and seafaring operations, pasture and grassland quality, environmental resources, access to external resources along with other related information. The survey was part of a larger programme to document land use, living conditions, population, and livestock numbers undertaken by the Danish king in response to a call for assistance by the Icelandic parliament Alpingi after a series of harsh winters at the end of the seventeenth century (Guðmundsson 1993: xix). The land survey covers almost the entire country - the records for the four easternmost counties were lost in the Copenhagen fire of 1728 , leaving records for 3560 of the roughly 4000 primary farms in the country (Table 1).

The items listed for every farm in the census. Paragraphs are always ordered in the same manner and a single paragraph is devoted to a single element of information: entries begin with the name of the farm; the first paragraph notes religious structures (if present), the second notes ownership, and so on.

These farmsteads, known as lögbýli, were the social units through which Iceland's administrative landscape was organized, and their status as such was neither gained nor lost easily. Fishing stations, trading sites, and harbour sites developed within a fixed structure of farmsteads that kept

\footnotetext{
1 "The correct and complete land census"
} 
Table 1 The structure and contents of an entry in the early eighteenth century land census Jarðabók Árna Magnússonar \& Páls Vídalín

Item Census text

Farm name

Ecclesiastical status

Value and tithe

Owner

Occupant

Rent

Rented livestock

Social obligations

Livestock

Hay production

Local resources

External resource rights

Pasture quality
Skrida (i Skriðuhverfi)

Skriða (in the Skriðuhverfi region)

Hálfkirkja eður bænhús hefur hjer að fornu verið, og stendur húsið enn, ekki hefur hjer embættað verið í manna minni.

The farm formerly had a half-church or a prayer house, and the structure still stands, but no services have been held here in living memory.

Jarðardýrleiki tíutíu hundruð með Skriðulandi, og so tíundast fjórum tíundum.

Value 100 hundreds including the tenant farm Skriðuland, and is tithed on all four parts ${ }^{\mathrm{a}}$

Eigendur Sr. Guðmundur, Sr. Ámundi og Torfi synir Sr. Páls sáluga Ámundasonar, sem hjelt Kolfreyjustað í Fáskrúðsfirði.

Proprietors Rev. Guðmundur, Rev. Ámundi and Torfi, sons of the late Rev. Páll Ámundason, formerly of Kolfreyjustaður in Fáskrúdsfjörður.

Ábúandinn Hallur Jónsson.

Occupant Hallur Jónsson.

Landskuld lx álnir nú og tvö fyrirfarandi ár, fyrir 12 árum ii $C$ undir 30 ár, fyrir 40 árum iii $C$ og ekki meiri so hjer undirrjettist. Betalast í landaurum nú sem stendur, og so atla menn að oftast hafi verið, og pykjast ekki vita að hjer hafi með jafnaði fiskatal verið áskilið.

Rent 60 ells the past three years, 240 ells twelve years ago, and so for 30 years prior. 360 ells forty years ago. Paid in land produce currently, and it is believed that was usually the case, although it is not known whether the proprietors ever demanded payment in fish.

Leigukúgildi vi inn til næstu 12 ára, nú i og næstu 2 ár, en pess í milli vita nálægir ekki grant að undirrjetta um kúgildisfjöldan. Leigan betalast í smjöri, og so var. áđur pá kúgildin voru vi.

Rented livestock 6 cow equivalents twelve years ago, and 1 for the past two years. Those nearby do not know the situation during the intervening years. The dues are paid in butter, both now and when the rented livestock numbered 6 cows.

Kvaðir öngvar.

No further tenant obligations.

Kvikfje iiii kýr, i kvíga veturgömul, xxxvii ær, xiii sauðir tvævetrir og eldri, xviii veturgamlir, xx lömb, i hestur, i hross, i foli prevetur, iii geitur, ii hauðnur.

Livestock 4 cows, 1 additional cow a winter-old, 37 sheep, 13 two-winter old rams and older, 18 winter-old rams, 20 lambs, 1 colt, 1 mare, 1 three-winter old foal, 3 goats, 2 kids.

Fóðrast kann vi kúa púngi, so sem nálægir pykjast næst komast eftir sinni hyggju, en áour hefur petta sæmileg heyskapargjörð verið, en afskaplega fordjörfuð af órækt bæði til túns og engja.

The farm can fodder 6 cow equivalents according to the estimates of those nearby, but the infield and the meadows are rather poorly due to improper management.

Útigángur góður meðan niðri nær, en mjög svipull fyrir fannlögum, og parf roskið fje hey nærri til helminga, og lömb mesta part fóður. Hestagánga í lakara lagi. Skógur til kolgjörðar að mestu eyddur, en til eldiviðar bjarglegur. Torfrista og stúnga bjargleg. Reiðíngsrista hefur verið, meinast eydd. Víðirrif nokkurt, brúkast til heystyrks.

Ranging and grazing for sheep is good when they can reach through the snow, but heavy snows are frequent, and for that reason mature sheep require fodder during winter amounting to nearly half their feed, and lambs are reared mostly on hay. Grazing for horses is on the poorer side. Woodland for charcoal making mostly destroyed, but woodland provides adequate firewood. Turf cutting is also adequate. The farm used to be able to cut saddle turf, but no more. Willow branches are used for firewood.

Reka á jörðina fyrir utan Litlufjöru milli Hellirs og Svínár og kallast Skriðureki. Rekavon par í minna lagi, pví festifjara er engin. Engjatak á jörðin takmarkað, pó lítið sje, í Hraunkots landi, sem Engibakki heitir, og hefur lengstum brúkast átölulaust. Ekki vita nálægir að undirrjetta greinilega um fleiri ítök jarðarinnar, pó rómur sje á að hún hafi i fyrstunni víðar nád, pá er pað fyrir lángvarandi brúkunarleysi mönnum fornt orðið, og verður ekki pví um pau fleira skrifað.

The farm has driftwood claims by Litlufjara between Hellir and Sviná, called Skriðureki. The area has poor driftwood prospects due to the lack of a good shore for the wood to settle in. The farm has a small claim on Hraunkot's pasture, called Engibakki, and has been used without dispute for a long time. Those present and nearby are not sure about other resource claims, although it is rumoured that in the first times they extended further. But, through persistent disuse, these have been made ancient in the minds of men, and for that reason will not be described further.

Túnið er fordjarfað af órækt og sprettur lítt, sem orsakast af leysingavatni, sem jetur úr rótina. Engið pornar upp og sprettur lítt og er mjög víða mosavaxið og graslítið. Úthagarnir eru miklir og sæmilega grösugir, og ljær ábúandi beit til Jódísarstaða sem áđur segir. 
Table 1 (continued)

\begin{tabular}{|c|c|}
\hline Item & Census text \\
\hline & $\begin{array}{l}\text { The infield is poorly maintained and grows but slowly, caused by water affecting the roots. The pasture is } \\
\text { dry and grows slowly, and is mossy in many places. There are large and rather grassy outfields, and the } \\
\text { occupant provides pasture to nearby Jódisarstadir. }\end{array}$ \\
\hline $\begin{array}{l}\text { Varia (risks to livestock, reservoir quality } \\
\text { and church road condition) }\end{array}$ & $\begin{array}{l}\text { Hætt er kvikfje fyrir Álfasíki og nokkrum lækjum. Vatnsból er erfitt fyrir fannlögum. Kirkjuvegur til Múla } \\
\text { gagnvænn. } \\
\text { Livestock is threatened by Álfasiki mire and some springs. Water springs can be difficult to access due to } \\
\text { snow cover. Church road to Múli in good condition. }\end{array}$ \\
\hline $\begin{array}{l}\text { Subsidiary tenant farm (unoccupied, listing } \\
\text { several features that were also listed for } \\
\text { the main farmstead, such as value and } \\
\text { rent when it was last occupied) }\end{array}$ & $\begin{array}{l}\text { Skriðuland, partur af Skriðu. Bygð niður frá heimatúninu fyrir manna minni, en eyðilagðist í bólunni, afdeilt } \\
\text { að túni og engjum og reiknaðist fjórðúngur allrar jarðarinnar meðan bygðin varaði, að dýrleika xxv C, og } \\
\text { só tíundast ut supra. } \\
\text { Landskuld lxx álnir, seinast bygt var., og so að fornu. Betalaðist með landaurum til heimabóndans eður } \\
\text { fiskatali. } \\
\text { Leigukúgildi iii. Leigan í smjöri til heimabóndans. } \\
\text { Kvaðir öngvar. } \\
\text { Fóðrast kunni, seinast bygt var., ij kýrpúngi. } \\
\text { Aftur má hjer byggja, ef fólk til fengist. } \\
\text { Skriðuland, part of Skriða. Built by the infield before living memory, but abandoned during the recent } \\
\text { smallpox (1707-1709), considered a quarter of the primary property while occupied, valued at } 15 \\
\text { hundreds and tithed accordingly. } \\
\text { Rent } 70 \text { ells while occupied, and so in former times. Paid with land produce or fish to the tenant on Skriða. } \\
\text { Rented livestock } 3 \text { cow equivalents. Rent paid in butter to the tenant on Skriða. } \\
\text { No further tenant obligations. } \\
\text { The farm could fodder } 2 \text { cow equivalents when it was last occupied. } \\
\text { Can be reoccupied if potential tenants are found. }\end{array}$ \\
\hline $\begin{array}{l}\text { A subsidiary tenant farm, abandoned for } \\
\text { over } 40 \text { years }\end{array}$ & $\begin{array}{l}\text { Skriðu Sel, forn eyðihjáleiga hjér í landinu út í skóginum, sem hefur í eyði legið vel } 40 \text { ár, og veit pví enginn } \\
\text { nálægur um hennar byggingarkosti að undirrjetta. Ekki má hjer aftur byggja, pví túnið er víði vaxið en } \\
\text { heyskapur enginn. } \\
\text { Skriðusel, ancient farm mound on the property by the woodland, which has been abandoned for at least } \\
40 \text { years, and for that reason no one present or nearby remembers the affordances of the farm. Not } \\
\text { suitable for reoccupation as the infield is overgrown with willow, and very little hay cutting is possible } \\
\text { here. }\end{array}$ \\
\hline $\begin{array}{l}\text { Archaeological features on the farmstead's } \\
\text { lands. }\end{array}$ & $\begin{array}{l}\text { Steinstader kallast örnefni sunnarlega í Skriðu landi, par atla menn að í fyrndinni hafi bygt verið, pó pess } \\
\text { jjáist mjög lítil merki tóftaleifa og girðinga, pví petta pláss er mestallt í blauta mýri komið og má pví hjer } \\
\text { ekki aftur byggja. } \\
\text { Steinstaðir is a place name in the southern part of the Skriða property. Men believe that it was inhabited in } \\
\text { ancient times, although there is little in the way of ruins to support that belief, and this place is mostly } \\
\text { mired nowadays and can therefore not be reoccupied. }\end{array}$ \\
\hline
\end{tabular}

${ }^{a}$ Tithe was traditionally divided in four, with one part going to the bishop, one to the parish priest, one to support paupers in the parish, and a final one to maintain the church property

urbanization in check and under the control of Iceland's elite the landowners (Karlsson 2000; for a discussion of village and community formation in Iceland, see Vésteinsson 2006). The lögbyli formed the core of Icelandic society from at least as early as the eleventh century (Gunnarsson 1987). The right to vote, the right to marry and a host of others were dependent on whether an individual was associated with a farmstead; only the primary tenant or owner of a farm was allowed to vote at assemblies and, in several circumstances, to marry (Gunnarsson 1987: 18-19). While the settlement structure expanded with additional farms, fishing stations, monasteries, and proto-industrial enterprises, these were always considered subsidiary units of a recognized lögbýli. On the surface, this society appears, then, to consist of atomized farmsteads in a fairly flat hierarchy; in fact, however, these farms were interconnected and interdependent in a multitude of ways, among them the itök.

\section{Ítök: Background}

Eighteenth century Icelandic society was agricultural, comprised of farmers on fairly small, individuated farms that relied on the land for various resources to feed their livestock, construct their houses, and provide cooking and heating fuel. A shortcoming of any of these required dealings with those who had a surplus of needed resources. The itak system is a manifestation of these characteristics.

Since Iceland's agricultural landscape is highly variegated, with farms located on the coastline and valley bottoms, and 
well into highland areas. Thus a farmstead, by virtue of its location, would have lacked certain environmental resources, and certain farmsteads may have a surplus of some resources while lacking others. In addition, a number of environmental resources were necessary to keep a farmstead operational.

Iceland never developed an agronomy based on cereal cultivation, although there is evidence for early reliance on the practice (Steindórsson 1948). Rather, Icelandic farmers primarily reared sheep, horses, and cattle, and occasionally goats, although earlier farming practices were notably different, including, for instance, pigs (Amorosi et al. 1997; McGovern et al. 2007; Vésteinsson et al. 2002). Sheep and horses require more or less the same kind of feed, and both were kept outdoors for most of the year although hay fodder was required for severe weather conditions. Sheep also grazed seaweed through the winter in certain parts of the country, notably in the north east and the western counties of Dalasýsla and Barðastrandarsýsla. Cows require more fodder and were kept close to the farm, or taken to shielings for a number of weeks in the summer. Practically every farm in the country had a mixture of these three livestock, and so would have required productive infields for cow grazing and hay making, meadows for hay, and outfield pastures for summer and winter grazing.

Many farmsteads also supplemented their food production with fish. Dried stockfish was also a common trade good, and hence important to fund purchases of essential goods that were not produced locally, such as whetstones, ropes, and iron tools (Gunnarsson 1987: 52-53). The majority of farmsteads did not have access to good landing sites by the sea, and so had to negotiate access with those farmers who had. Certain areas also developed into fishing stations for whole communities, such as Hjallasandur in Snæfellsnes. More commonly, though, farms with good natural harbours sold or traded access to them to individuals who constructed boathouses and sent farmhands to row out before the harvesting season.

Farmsteads also required a source of fuel, which is recorded in the land census for the majority of the approximately 3600 farmsteads listed. The two most common were wood charcoal and peat. Some coastal farms used driftwood or seaweed, and those without access to any of the above resorted to livestock manure for fuel. The census indicates that the last two were the least efficient (e.g., Magnússon and Vídalín 1913-1943 III: 26-34), and recent research on seaweed (Mooney 2018) shows how poorly it performs as a fuel source.

Most farmstead structures at the time were made using three main materials: timber, turf, and sod. A typical house consisted of thick outer walls of sod lined with turf on both sides, sometimes laid on a stone foundation. Inside, a timber frame supported a roof made of branches, beams, and turf strips. Lighter timber, skins, or textiles could then be used to segment the internal space of the house (Ágústsson 1998).
Iceland had lost much of its native woodland by the eighteenth century ('órhallsdóttir 2001), and in any case the native Betula pubescens was not very well-suited to the typical internal frame of a turf house. Instead most houses were built with driftwood, with native wood species used for roofing and insulation (Fig. 1). The best areas for driftwood were the northern shores and in particular the north western and north eastern extremes, where driftwood primarily from Siberia settled (Eggertsson 1993). By contrast, Iceland's settlement reached far inland (Fig. 2).

\section{The Assessment of Driftwood Prospects in the Census}

\section{Early Eighteenth-Century Settlement in Iceland}

Turf was easier to access for most of the farmsteads in the early eighteenth century, but it is by no means trivial. Ideal building turf comes from mires as sedge grasses, particularly Carex nigra, form a dense root structure that does not crumble once the turf dries (Stefánsson 2013: 17). While most farmsteads had access to wetlands - certainly a higher number than those with ready access to driftwood - hundreds of farms did not and thus relied on nearby farms for the resource (Fig. 3). As I illustrate below, the resource claim system is overwhelmingly designed to ensure access to these resources.

Iceland had a somewhat unusual economy throughout the middle ages and early modern periods, with no minted money aside from insubstantial amounts of Danish coin in circulation (Karlsson 2000). However, while it is true that Iceland did not have a monetary economy until well into the nineteenth century, there was a well-established system of valuation that, at least in the eighteenth century was ubiquitous throughout the country. This system was hexagesimal, equating one cow to six sheep, 120 ells (roughly a metre each) of woven wool, and $240 \mathrm{~kg}$ of fish. It system operated very much like a monetary system; as Graeber (2011) argues, money is in some ways simply a mathematical abstraction of the relative prices of things, although societies without currency tend to rely on debt rather than direct exchange, and there is evidence that medieval Iceland fits that model. ${ }^{2}$ What is more important for the purposes of this paper is that Iceland had barely anything that could be called an open market for domestic trade.

The Danish crown kept a monopoly on foreign trade in the early eighteenth century, but the merchants at these market harbours traded imported goods for local produce (Gunnarsson 1987). Anyone looking to trade one domestic good for another could have found potential trading partners at these harbours; a mid-eighteenth century account notes that during the annual sorting of sheep brought down from the uplands at the end of summer, a number of people from coastal settlements brought dried fish and other goods and that the

\footnotetext{
${ }^{2}$ E.g., Diplomatarium Islandicum XV, pp. 473-545.
} 


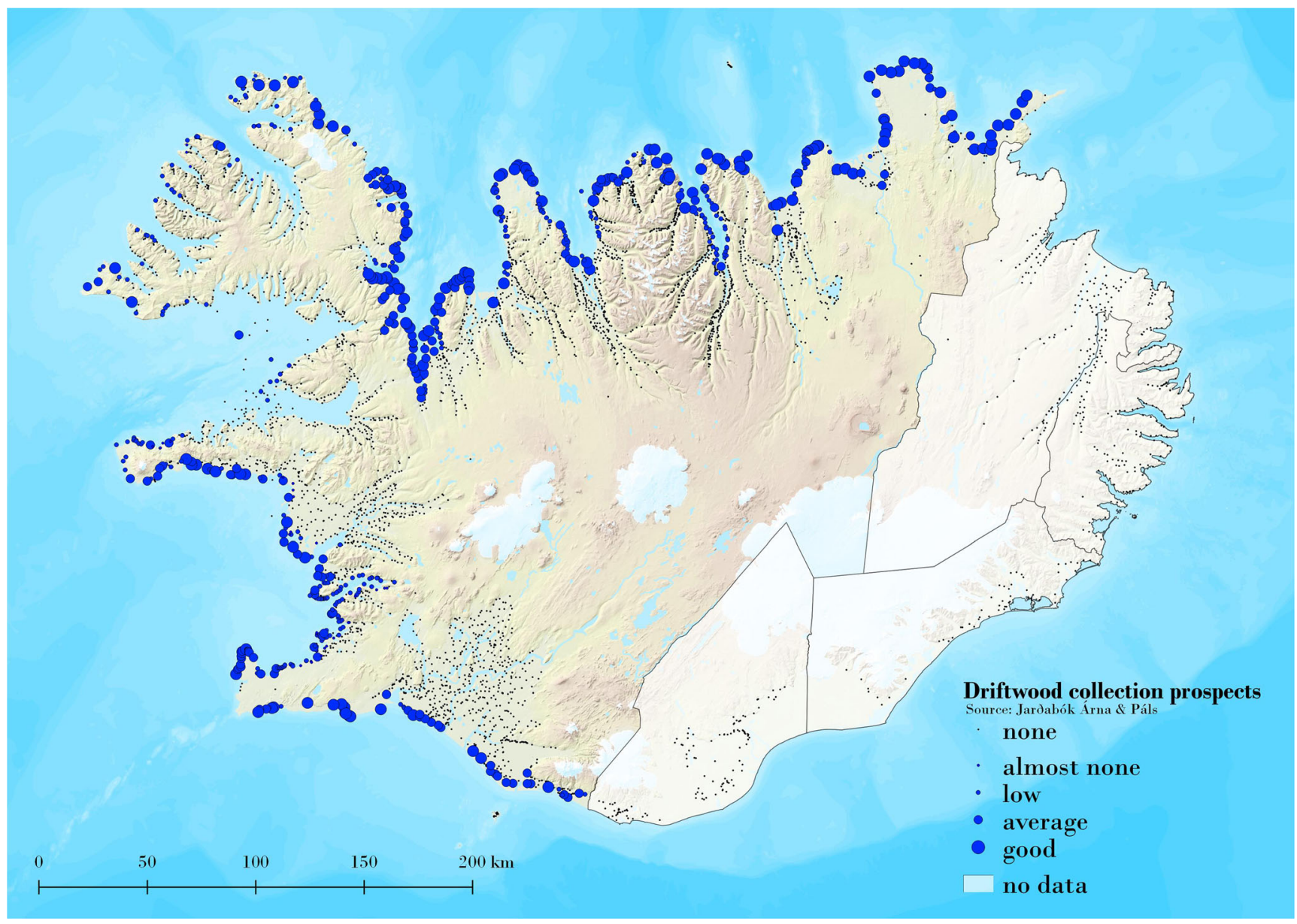

Fig. 1 Driftwood collection prospects

sheep fold formed "something resembling a market"(Ólafsson and Pálsson 1974: 105). In addition, early thirteenth century references to price standardization and laws regulating the length of units of spun wool (is. vaðmál) show that trade took place at assemblies. ${ }^{3}$ It is not unreasonable to assume that similar practices occurred at the market harbours. Neither it is unreasonable to assume that people used the opportunity afforded by communal events to trade goods. This has yet to be conclusively borne out in the archaeological record, however, although the only investigation to date is Mehler's (2015) investigation of trade practices at the national assembly site at Pingvellir, where she makes a strong argument that trade did not play a significant role.

I suggest that a good deal of domestic trade was negotiated directly between one farm and another, although third party mediation, usually from large landholders, was common. I discuss the evidence we have for such instances of mediation below, but for now I wish to stress that the lack of marketplaces where farmers were able to purchase required portable goods like firewood and building timber led to specific arrangements of exchange. Moreover, as indicated above, many

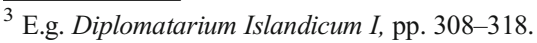

of the required resources such as pasture and turf cutting, were not durable and could not be stockpiled easily.

Every resource claim listed in Jarðabók Árna Magnússonar \& Páls Vídalín.

\section{Ítök: Overview}

There are 1963 claims listed for the 3556 farmsteads in Jarðabók Árna Magnússonar \& Páls Vídalin, or roughly two claims for every three farms (Fig. 3). The distribution by county varies considerably (Table 2). At one end, the total number of claims in Barðastrandarsýsla is only $14 \%$ of the number of farms in the county, whereas it is $128 \%$ in Norður-Pingeyjarsýsla. This might due to differences in recording methodologies among the different counties or a variation in thoroughness. For instance, there is a positive correlation between the length of a description, averaged per county, and the number of claims listed. ${ }^{4}$ The longer the description, the more likely it is to include references to resource claims. It is also possible that these differences are due to

\footnotetext{
$\overline{{ }^{4} \text { Corr: } 0.5135901} \mathrm{t}=2.1582, \mathrm{df}=13, p$ value $<0.05$.
} 


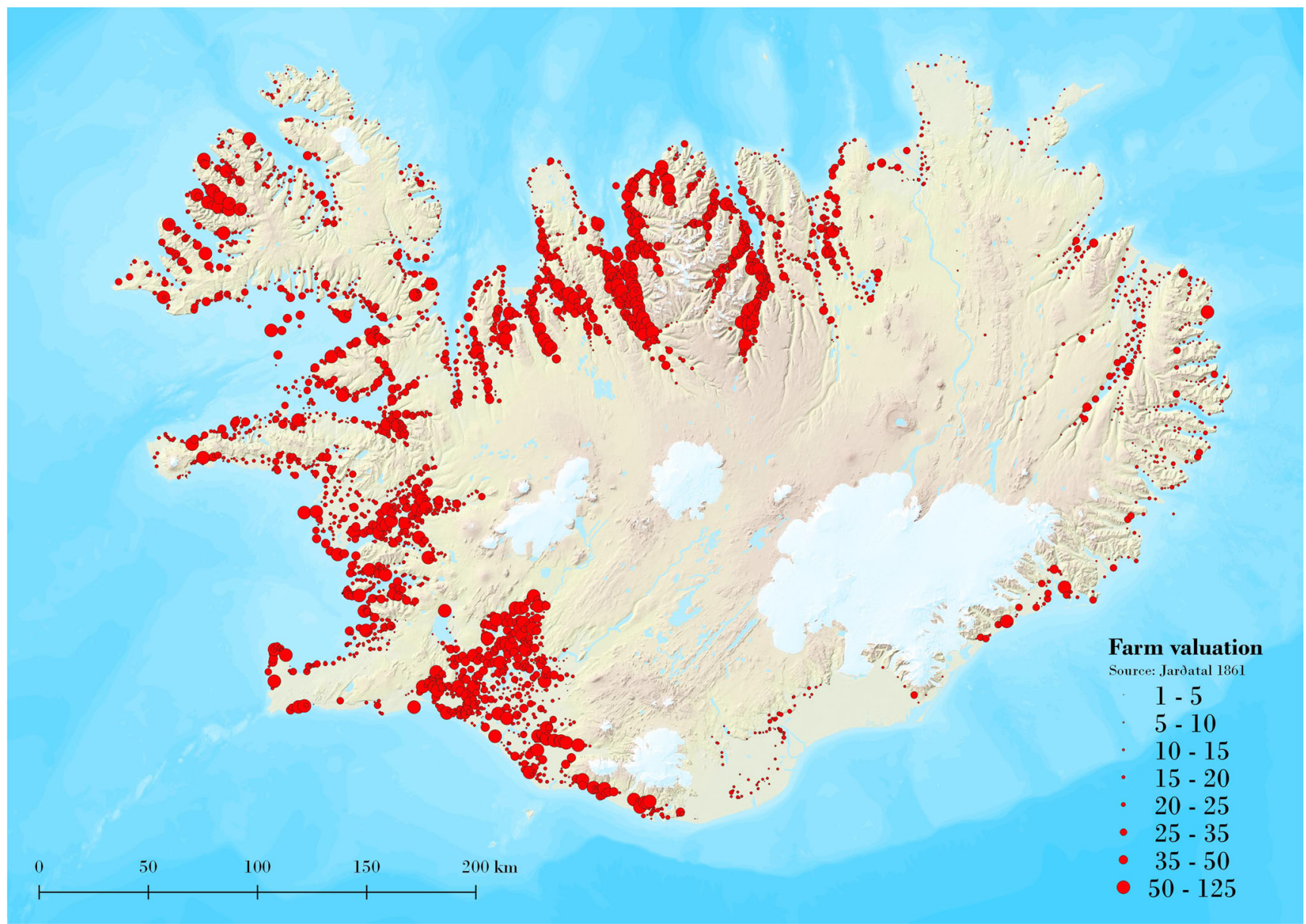

Fig. 2 Farm settlement pattern and valuation in the nineteenth century

regional variation, although that is beyond the scope of this paper.

\section{Distribution of Farmstead Claims}

Two hundred and eleven of the 1963 claims are relict. Many of these have become disused for two reasons. Firstly, a claimed resource may have been used up by the early eighteenth century. In addition, many claims simply involved too much effort to exercise. It is interesting to note that the claims are listed regardless and dated roughly to when they were last enacted. This temporal phasing in the Jarðabók text is divisible into four phases: now, recently, in living memory, and before living memory. The last phase indicates that many of these claims were written down, mostly in church inventories (is. máldagi). The claims were recorded at gatherings where every farmer in a given community was expected to be present in order to ensure that a farmer's description of his or her lands could be verified by neighbouring farmers, and disputes certainly occurred. Some claims were dormant as a consequence of being contested by a landowner, and the assemblies did not always pick sides. The more common reason for disputes was a discrepancy between the information in church registers and what the assembly of farmers considered to be accurate. For instance, the priest at Stafholt in western Iceland insisted that the parish church had fishing rights to the nearby river bverá, based on church records dating back to the twelfth century and repeatedly listed in later documents. The farmers by the river, however, disputed the claim and the surveyors noted that the claim had rarely been exercised in living memory (Magnússon and Vídalín 19131943, IV: 333-335). Disputes of this kind indicate that Icelandic society had a form of adverse possession whereby anyone using a resource uncontested for 20 years would gain rights to it, and anyone who failed to exercise their claim for 20 years would lose rights to it (e.g., Kristjánsson 1980: 224).

The land census was conducted in a transitional period where written sources were clearly considered legitimate evidence for claims, but there are plenty of cases where local farmers express displeasure about these due to continued disuse. Many of the written sources have also clearly been copied from older church registers, and so the claims described in them may not have been used for centuries. Nevertheless, it is tempting to think that continuing to assert the legitimacy of claims had some value, even if it was clear that they would never be exercised again. The claims represent a degree of control that one farm asserts over another, and perhaps that 


\section{Early 18th cenetury resource claims in Jarðabók Árna Magnússonar \& Páls Vídalín}

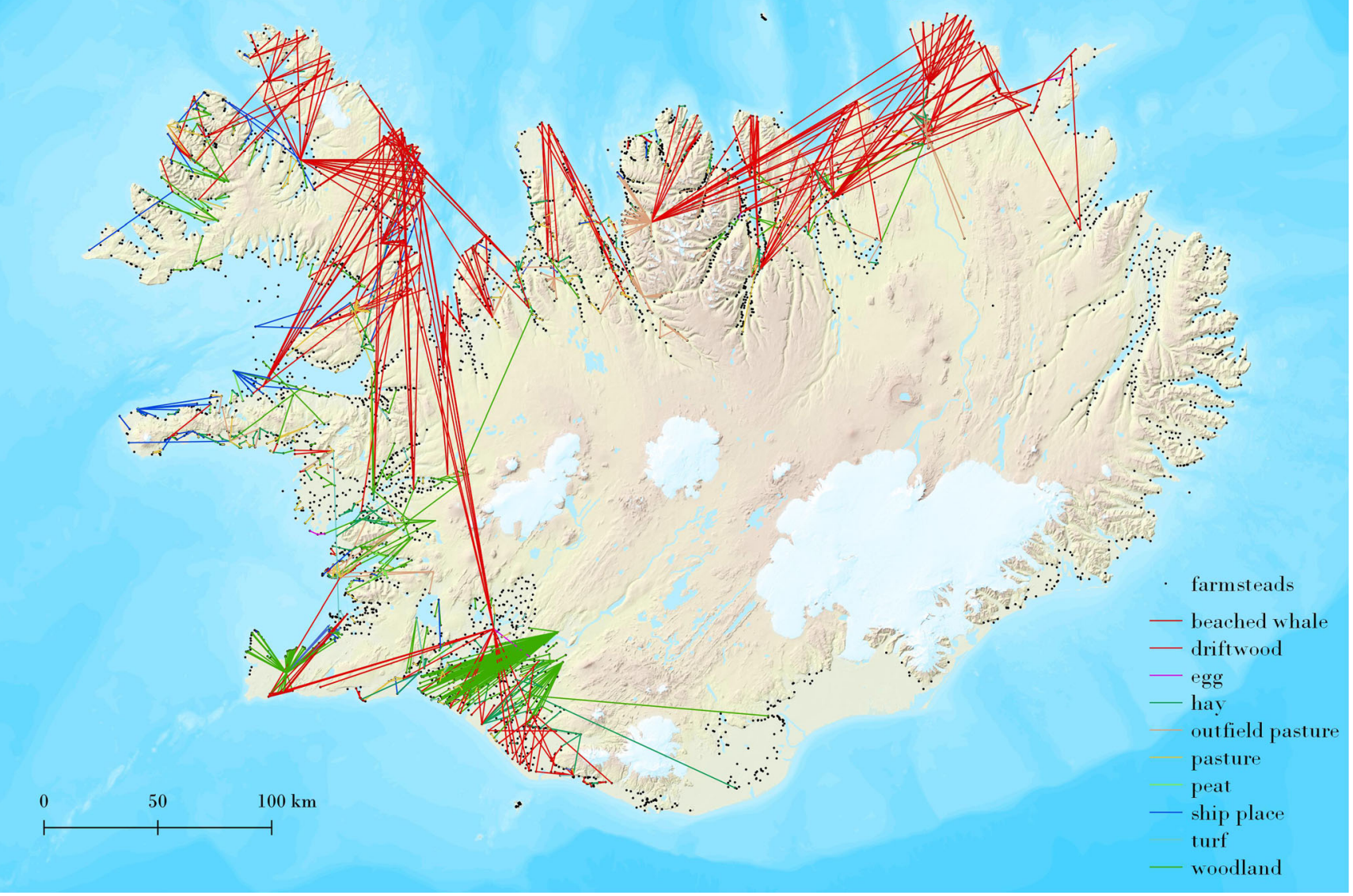

Fig. 3 Resource claims in the eighteenth century

Table 2 The number of claims and farmsteads ordered by county

\begin{tabular}{|c|c|c|c|c|}
\hline County & Claims & Farmsteads & Ratio & $\begin{array}{l}\text { Mean character length of } \\
\text { farmstead descriptions }\end{array}$ \\
\hline Barðastrandarsýslur & 24 & 172 & 0.139535 & 2075 \\
\hline Eyjafjarðarsýsla & 112 & 344 & 0.325581 & 1547 \\
\hline Árnessýsla & 140 & 355 & 0.394366 & 2045 \\
\hline Rangárvallasýsla & 111 & 258 & 0.430233 & 2034 \\
\hline Dalasýsla & 79 & 180 & 0.438889 & 1710 \\
\hline Suður-bingeyjarsýsla & 112 & 242 & 0.46281 & 1817 \\
\hline Mýrarsýsla & 118 & 245 & 0.481633 & 1946 \\
\hline Borgarfjarðarsýsla & 125 & 210 & 0.595238 & 1920 \\
\hline Húnavatnssýsla & 190 & 350 & 0.542857 & 2256 \\
\hline Strandarsýsla & 75 & 122 & 0.614754 & 1970 \\
\hline Skagafjarðarsýsla & 240 & 339 & 0.707965 & 1494 \\
\hline Ísafjarðarsýslur & 195 & 255 & 0.764706 & 2141 \\
\hline Snæfells- og Hnappadalssýsla & 155 & 179 & 0.865922 & 2702 \\
\hline Gullbringu- og Kjósarsýsla & 182 & 196 & 0.928571 & 3202 \\
\hline Norður-Pingeyjarsýsla & 105 & 82 & 1.280488 & 2264 \\
\hline Total & 1963 & 3532 & & \\
\hline
\end{tabular}




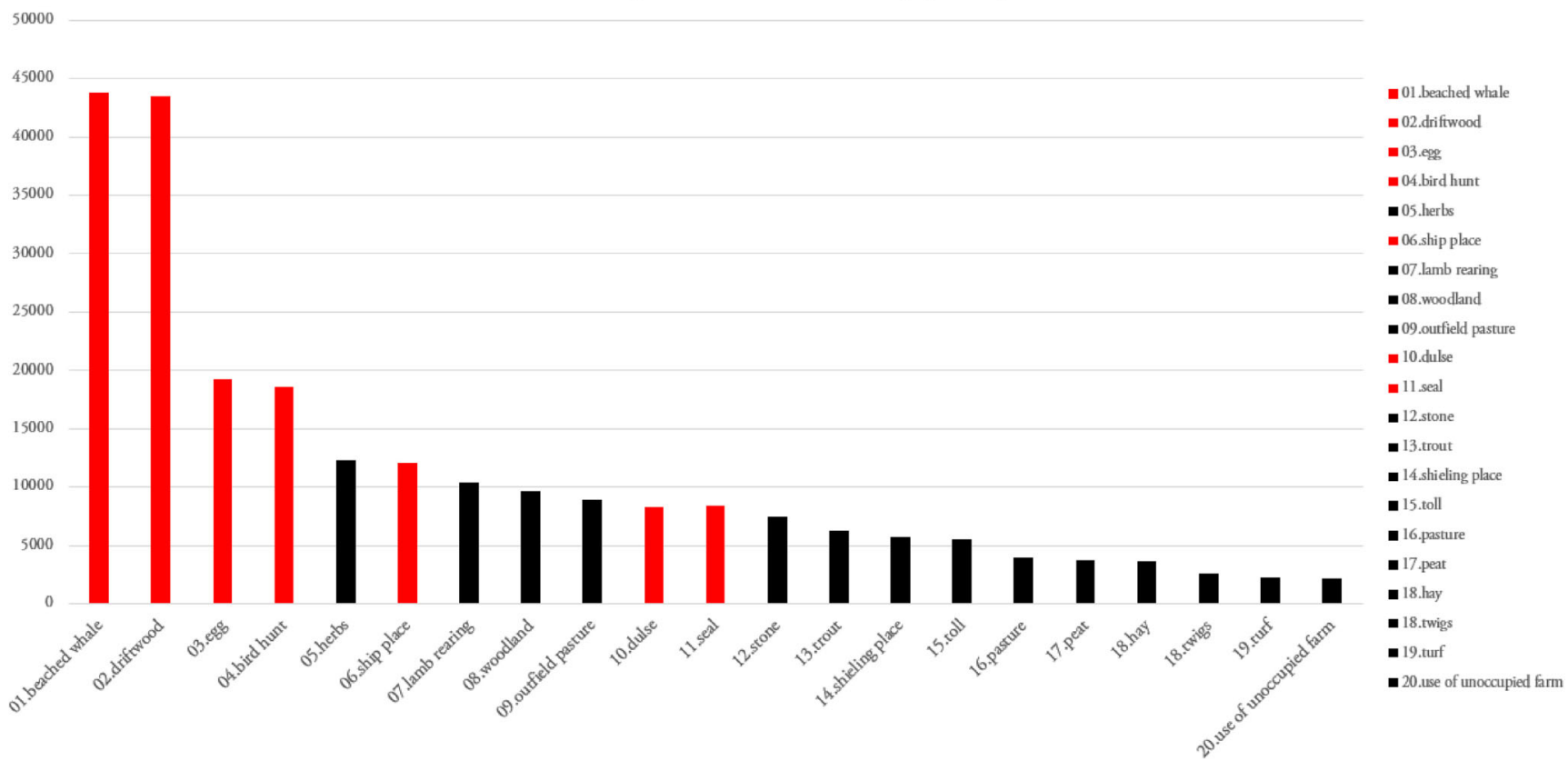

Fig. 4 The average distance of claims, ordered by resource type. Red bars indicate predominately marine and coastal resources while black bars indicate terrestrial resources

control could be leveraged in other ways than directly exercising the claim itself (Fig. 4).

\section{Characterising Connectivity}

I propose a tentative categorisation of the claims that, while by no means mutually exclusive, reflect general trends in the dataset that lead to fairly useful divisions.

\section{Coupled Subsistence}

Roughly 350 of the claims represent some sort of exchange between two farms. These farms, totalling 274 , are usually either contiguous neighbours or located nearby one another. The exchanges generally involved trades that align well with the variegated character of Iceland's landscape. For instance, a coastal farm might have traded sea access on their land for pasture access from a neighbouring inland farm. There were many instances of farms with good meadows engaged in a resource exchange with farms that had good pastures. These binary systems could have arisen for a variety of reasons. They may indicate that the two farms in question formed a larger unit earlier, which was then divided into two or more properties. This was a common practice in Iceland, especially in the first few centuries of settlement (Vésteinsson and McGovern 2012). It may also be an example of the spreading of risk between two farms as a way of counteracting Iceland's notoriously capricious environment and climate. The final, and most straightforward explanation is that this practice made eminent sense considering Iceland's landscape. In any event, by the eighteenth century it is clear that a significant number of farms were tied to one or more neighbours through dynamics of symmetrical interdependence. Living off the land relied on coupling, both in order to extend by proxy the area of the farm to include all of the vital resources needed to survive, as well as hedging some risk in case of disaster.

It is worth exploring who owned these 274 farmsteads. The land census contains ownership information for every farmstead, including where the owner is based. I have mapped this as a network (Pálsson 2018) and categorised the ownership type into four categories - private, episcopal, royal and ecclesiastical ownership (Table 3 ). There is a statistically significant ${ }^{5}$ difference between exchange claims sorted by the four ownership types, with roughly $10 \%$ of the farmsteads owned by the king and either of the two bishoprics engaged in resource exchange, while only $5.5 \%$ and $5.9 \%$ of the farmsteads owned by churches and individuals, respectively. The bishoprics and Danish Crown were the three largest landowners in Iceland by a major margin throughout the post-Reformation period, with the Danish crown owning 632 farmsteads and the two bishoprics a combined 646 farmsteads. The 168 landholding church farms, in contrast, owned a combined 604 farmsteads, or 3.59 farmsteads each on average. The rest of the just over 1800 farms were owned by 904 individuals, or 2 farmsteads on average. ${ }^{6}$

\footnotetext{
${ }^{5}$ Pearson's Chi-squared test: $\mathrm{X}$-squared $=23.764, \mathrm{df}=3, p$ value $=0.00002798$.

${ }^{6}$ The total number of farms by this measure is slightly higher than the 3532 listed above, as some farms are partly owned by two or more owners, leading to some farmsteads being counted twice when comparing ownership types and claim types.
} 
Table 3 Properties by proprietor type

\begin{tabular}{lllll}
\hline & Bishop & Church & King & Individual \\
\hline Total properties & 646 & 604 & 632 & 1804 \\
Average properties per proprietor & 323 & 3.6 & 632 & 2 \\
Properties involved in exchange claims & 68 & 33 & 62 & 110 \\
Percentage of farmsteads involved in exchange claims & $10.5 \%$ & $5.5 \%$ & $9.8 \%$ & $5.9 \%$ \\
\hline
\end{tabular}

The much more frequent occurrence of exchange claims in the royal and episcopal property assemblages suggests that, rather than being a practice between small landholders, exchange claims are predominately found as a mechanism employed by the larger landholdings more likely to have surplus resources to exchange to increase the sustainability of a number of its properties. It was a double bind for the tenant, however - not only did he or she have to pay rent, but had to also participate in this material dispersal across their landlord's properties. There are recorded complaints about this type of obligation (see below).

\section{Frequency of Exchange Claims on Farms Sorted by Ownership Category (Fig. 5)}

\section{Centre-Oriented Assemblages}

This category includes more complex arrangements involving more than two farmsteads with several clusters of claims centred on a single farm. These centres were predominately large farmsteads that played an important role for much of Iceland's history before the eighteenth century (and in many cases well into the present). An example of this is Holt in Rangárvallasýsla (Fig. 6). Holt is a large property, likely settled in Iceland's settlement age in the ninth century (Buckland et al. 1991). A thirteenth century church register lists its resource claims (Diplomatarium Islandicum II, pp. 84-86, translation by author):

The holy church of Holt owns ... half of SyðstuVesturholt's shores, same at Bakki, woodland in Pórsmörk ... pasture in Vesturholt, pasture in Lambafell.

\section{Holt Church Landholdings}

These claims remain listed in the eighteenth century land census, although Holt had increased its claims somewhat. However, the main difference between the medieval church inventories and the eighteenth century land census is the number of claims that neighbouring lands had on Holt. Almost all of the neighbouring farms had a claim on Holt's driftwood, and nearby Vesturholt had rights to turf cutting in Holt (Fig.
6). Holt was not only in a position to extract resources from nearby farms, but it also provides resources to its neighbours most notably a supply of driftwood. This is not surprising given its historic role in the area as a magnate farm that quickly secured driftwood rights to significant stretches of the nearby coastline and woodland rights in the forests in the uplands to the north. It became the parish church when the parish system was established late in the twelfth century, and remained the largest farm in the region until at least the nineteenth century.

Holt also owned many of the farms that have driftwood claims on it, although not all of them. In fact, Holt owns the farmsteads by the sea, whereas the driftwood claimants that Holt does not own sit higher in the landscape, at the foot of the Eyjafjöll mountain range to the north. They are also considerably more valuable farms than Holt's subsidiary properties. One suggestion for this arrangement is that Holt and the farms to the north were initially part of one large land claim, reminiscent of the so-called Skallagrim effect, named after the colonizing party that claimed a vast area in western Iceland and positioned farmsteads in strategic locations near key resources, while maintaining the farmstead Borg as a central place within the land claim (Smith 1995; Vésteinsson et al. 2002). According to that interpretation, Holt may have been the centre of an internally coordinated area including the northern farms of Núpur, Yzti Skáli, Miðskáli, and Ásólfskáli, from which the sourcing and dispersal of driftwood for every farm in the area was organized.

It is also possible to think of the Holt assemblage as a scaled-up version of the first category. In fact, the driftwood claims of the southern farms Nýibær, Bakki, and Vesturholt is something of an accounting trick. In fact, Holt actually owned driftwood rights to the entire shoreline of these farms, which consequently had limited claims to driftwood on their land, and the land census records these as claims by Nýibær, Bakki and Vesturholt on Holt. Setting aside the awkward wording, the agency of resource control lay predominately with Holt. The other exchange that took place between Holt and its neighbours to the north resembles even more closely a version of the coupled subsistence category, whereby one side - Holt and its subsidiaries control a coastal resource, while the other - the moderately large farmsteads positioned at the foot of Eyjafjöll - control an upland resource.

Ölfus landholdings. 


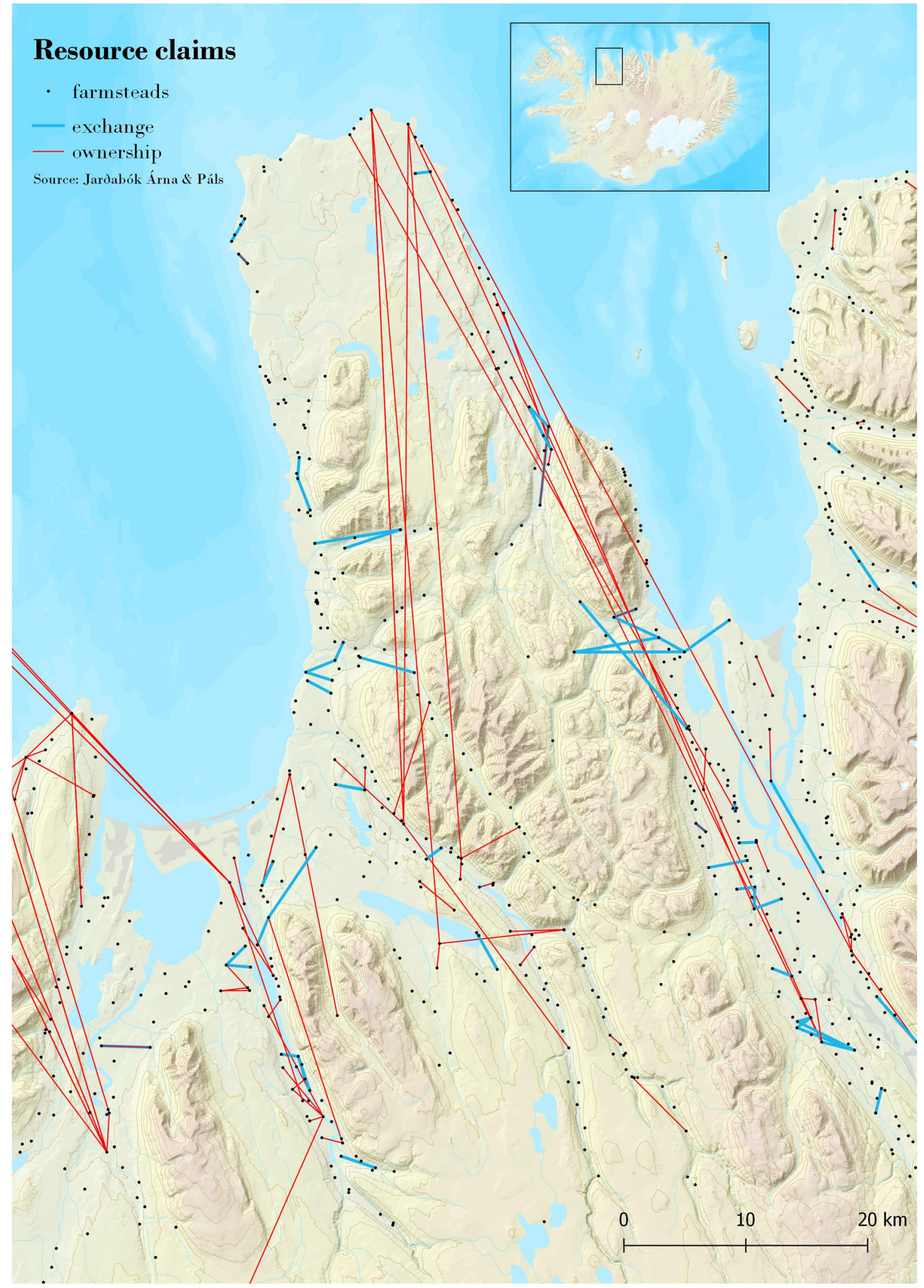

Fig. 5 Northern Iceland is characterised by a high number of resource exchanges between neighbouring farmsteads 


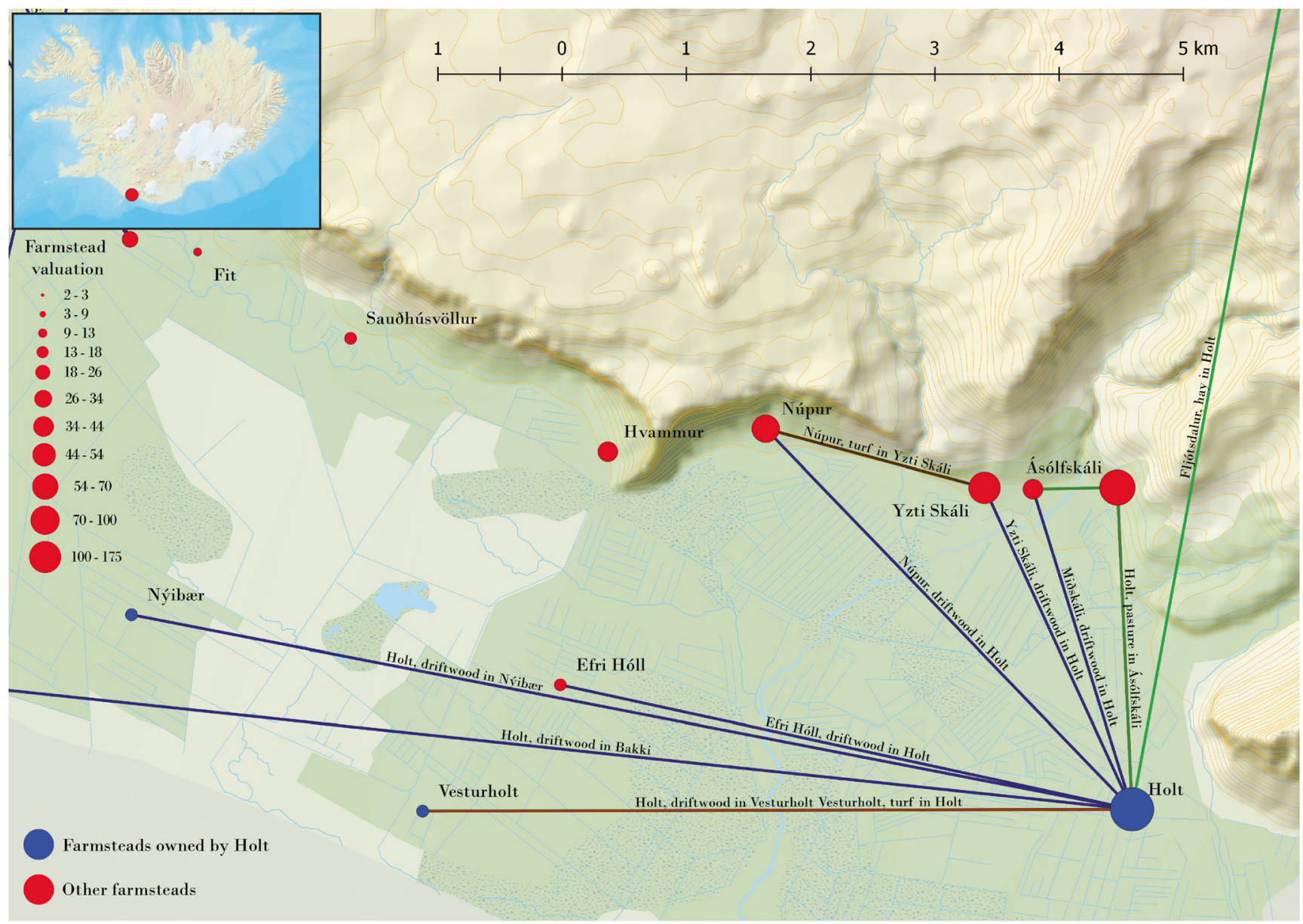

Fig. 6 Claims centred on Holt

\section{Ölfus Resource Dispersal}

Although a thorough discussion of these assemblages is beyond the scope of this paper, I note a few more to illustrate their variety. In some cases there was not a clear central farm to speak of. The farmsteads along the southern coast by Ölfus were connected by several two-way resource exchange claims. By scale they do not quite fit into the first category, but again the function is quite similar. The Ölfus case may have formed early, although there are unfortunately no written records that mention these claims before the eighteenth century. Whether it developed out of an initial land claim or not, it is clear that by the eighteenth century the Ölfus farms had developed an extensive system of resource dispersal involving eight farms (Fig. 7 and Table 4). Similar to Holt, this is a picture of terrestrial and marine resource exchange, but flowing in an irregular fashion in contrast to the barycentric flows of the Holt example.
Other cases centred on a resource rather than a farmstead. At the smaller end of the scale, a valuable resource may have been managed cooperatively by a number of nearby farmsteads. The cascades Laxfoss in Laxá í Kjós, still famous for its salmon fishing, was managed by five farmsteads, three of which had access to it once a week and the other two twice a week. It is interesting to note that these farmsteads did not include all those whose land borders the river nor does the influential nearby church farm Meðalfell have any claims to Laxfoss (Fig. 8). In other words, two key assumptions in historical network reconstruction - proximity and social influence (see Brughmans 2013, 629-630) do not appear to be primary drivers behind the formation of the Laxfoss resource network.

Commons (is. Almenningar) were found throughout the country and usually operated in one of two ways: some were owned by a single magnate farm and used at their discretion, often for a fee (akin to a common property regime, see Ostrom 1990); others were managed and/or used by farm communities 


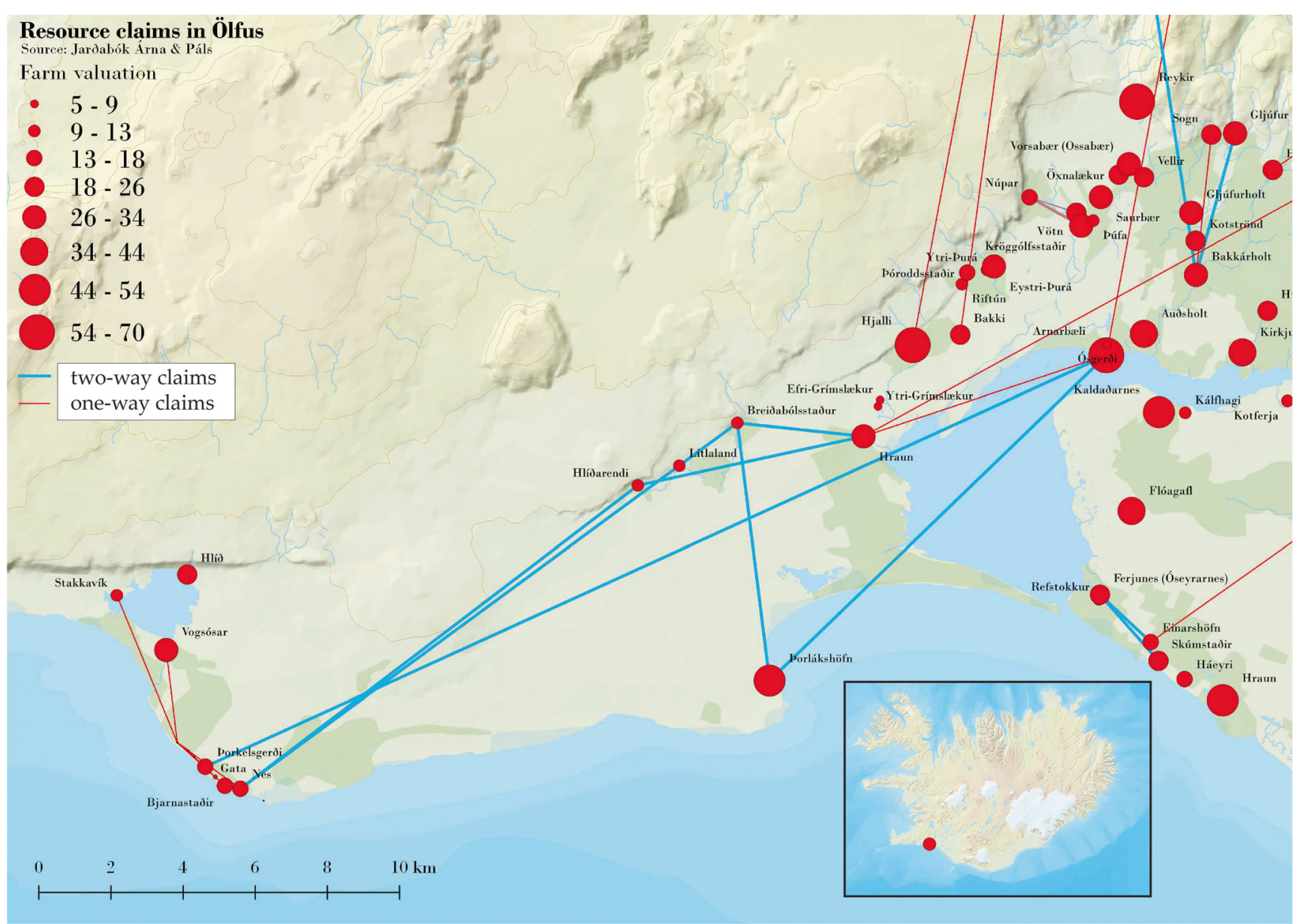

Fig. 7 Resource claims in Ölfus

(is. hreppur), the main example being upland summer grazing areas (is. afréttur), and subject to various restrictions recorded in Iceland's law codes (e.g., Karlsson et al. 1992: 321-324). Most of the farms in the southwest of Reykjanes peninsula produced charcoals in the same commons, and shared uplands were the norm across the country although in some instances the uplands were owned and leased out by magnate farms (e.g., Svínavatn in Húnavatnssýsla). These are similar phenomena to the resource-centric assemblages, but operating at a much larger scale.

Figure 9 shows a distribution, The distribution of farmstead centre-oriented assemblages, defined provisionally as those farmsteads with four or more claims on other properties combined with claims on the farmstead itself, is fairly even across the study area, with notable clusters in the north east and a somewhat higher density throughout the north. It is clear that the overwhelming majority of these farmsteads are the historic power centres in the country (Fig. 9). Over $75 \%$ of the farmsteads in question are parish church centres, influential farmsteads that dominated Iceland's political landscape for most of its history (Fig. 10), ${ }^{7}$ reflecting the way that power influences land use.

Distribution of farmstead centre-oriented assemblages.

\section{Parish Church Farmsteads}

\section{Magnate/Semi-State Systems}

Occasionally, centre-oriented systems grew so large in scale that they merit their own category. There were only a handful of these in eighteenth century Iceland. By far the largest were the two bishoprics, Skálholt and Hólar, followed by the royal

\footnotetext{
7 These numbers do not include claims that had been relict for a long time by the eighteenth century. Even so, it is possible that this number is skewed by a representative bias, as the main sources for itak claims before the eighteenth century are church registers. In fact we have very scant records of itak claims not involving church farms before the eighteenth century. In any event, it is likely that the writing down of claims meant that claims involving church farms were much less likely to become forgotten or disused, as priests could (and did) continue to claim rights to resources by referencing centuries-old church documents.
} 
Table 4 Resource claims in Ölfus

\begin{tabular}{|c|c|c|c|}
\hline Farm 1 & Farm 2 & Resource & Notes \\
\hline Arnarbæli & Porlákshöfn & ship place & $\begin{array}{l}\text { Engjatak á jörðin á Arnarbælisengjum, og er pað kallað Tiuaura engi, aðrir nefna Stakksengi. Рað brúkar } \\
\text { Porlákshöfn árlega, en staðurinn Arnarbæli par í mót áttæríngs skipsstöðu í Porlákshöfn, og er ekki fyrir } \\
\text { goldið pó stærri skip gángi. } \\
\text { Porlákshöfn has access to Arnarbali’s meadows, called both Tiuaura meadow and Stakks meadow. } \\
\text { Porlákshöfn uses it yearly, and in return Arnarbali rows to sea from Porlákshöfn's harbours. }\end{array}$ \\
\hline Arnarbæli & Porkelsgerði & ship place & $\begin{array}{l}\text { Annað skipsuppsátur að Porkelsgerði i Selvogi fyrir tólfæring. } \\
\text { Ship place in Porkelsgerði in Selvogur for a 12-oared boat. }\end{array}$ \\
\hline Breiðabólsstaður & Porlákshöfn & ship place & $\begin{array}{l}\text { Skipsuppsátur á jörðin í Porlákshöfn fyrir selstöðu í heimalandi. } \\
\text { Breiðabólsstaður has a ship place in Porklákshöfn in exchange for a shieling place. }\end{array}$ \\
\hline Breiðabólsstaður & Hraun & hay & $\begin{array}{l}\text { Engjatak á jörðin og brúkar árlega á Hraunsengi, par sem heita Lambeyrar. Par í mót segja menn, að Hraun } \\
\text { eigi lýngrif á } 30 \text { hesta annaðhvort ár í Breiðabólstaðarlandi NB, vide Hraun supra. } \\
\text { Breiðabólsstaður has access to Hraun's meadows, in a place called Lambeyrar. In exchange it is said that } \\
\text { Hraun can harvest enough twigs to load } 30 \text { horses, every other year, in Breiðabólsstaðir's land. }\end{array}$ \\
\hline Breiðabólsstaður & Nes & dulse & $\begin{array}{l}\text { Sölvafjöru á jörðin í Selvogi fyrir Neslandi fyrir hrossabeit um sumur. Enginn segir hjer hvað margra. Hitt vita } \\
\text { menn, að sölvaítakið brúkast árlega. } \\
\text { Breiðabólsstaður owns a dulse beach in Nes' land in exchange for summer grazing for horses. No one is sure } \\
\text { how many horses can graze, but the dulse is picked every year. }\end{array}$ \\
\hline Hlíðarendi & Nes & dulse & $\begin{array}{l}\text { Sölvafjöru á jörðin i Selvogi fyrir Neslandi, par sem kallast Hliðarendabás. Par i mót eiga Selvogs ábúendur } \\
\text { frí að láta reka búsmala sinn yfir Hlíðarendaland til brynníngar að Hlíðarendalæk, skamt frá túninu, og } \\
\text { petta um sumartíma frá Nesseli, sem stendur á Selvogsheiði. }\end{array}$ \\
\hline Hlíðarendi & Hraun & hay & $\begin{array}{l}\text { Engjatak á jörðin i Hraunslandi takmarkað par sem kallað eí Hlíðarendaengi. Hjer i mót, segja menn, að } \\
\text { Hraun eigi á } 12 \text { hesta lýngrif á vor og aðra } 12 \text { á haust í Hlíðarendalandi, hefur pó sjaldan brúkast, en } \\
\text { engjatakið frá Hlíbarenda árlega. }\end{array}$ \\
\hline Hraun & Hlíðarendi & pasture & $\begin{array}{l}\text { Engjatak á jörðin i Hraunslandi takmarkað par sem kallað eí Hlíðarendaengi. Hjer i mót, segja menn, að } \\
\text { Hraun eigi á } 12 \text { hesta lýngrif á vor og aðra } 12 \text { á haust í Hlíðarendalandi, hefur bó sjaldan brúkast, en } \\
\text { engjatakið frá Hlíbarenda árlega. }\end{array}$ \\
\hline Hraun & Breiðabólsstaður & $\begin{array}{l}\text { twigs and } \\
\text { branches }\end{array}$ & $\begin{array}{l}\text { Engjatak á jörðin og brúkar árlega á Hraunsengi, par sem heita Lambeyrar. Par í mót segja menn, að Hraun } \\
\text { eigi lýngrif á } 30 \text { hesta annaðhvort ár í Breiðabólstaðarlandi NB, vide Hraun supra. } \\
\text { Breiðabólsstaður has access to Hraun's meadows, in a place called Lambeyrar. In exchange it is said that } \\
\text { Hraun can harvest enough twigs to load } 30 \text { horses, every other year, in Breiðabólsstaðir's land. }\end{array}$ \\
\hline Nes & Hlíðarendi & spring water & $\begin{array}{l}\text { Sölvafjöru á jörðin i Selvogi fyrir Neslandi, par sem kallast Hliðarendabás. Par i mót eiga Selvogs ábúendur } \\
\text { frí að láta reka búsmala sinn yfir Hlíðarendaland til brynníngar að Hliðarendalæk, skamt frá túninu, og } \\
\text { petta um sumartíma frá Nesseli, sem stendur á Selvogsheiði. } \\
\text { Hliðarendi owns a dulse beach in Nes' land, called Hliðarendi's booth. In exchange, Nes are allowed to send } \\
\text { their cowboy to water the animals in Hliðarendi's brook, nearby the infield. This occurs in summer, with the } \\
\text { animals coming from Nes' shieling in Selvog's heath. }\end{array}$ \\
\hline Nes & Breiðabólsstaður & pasture & $\begin{array}{l}\text { Sölvafjöru á jörðin í Selvogi fyrir Neslandi fyrir hrossabeit um sumur. Enginn segir hjer hvað margra. Hitt vita } \\
\text { menn, að sölvaítakið brúkast árlega. } \\
\text { Breiðabólsstaður owns a dulse beach in Nes' land in exchange for summer grazing for horses. No one is sure } \\
\text { how many horses can graze, but the dulse is picked every year. }\end{array}$ \\
\hline Porkelsgerði & Arnarbæli & hay & $\begin{array}{l}\text { Engjatak á jörðin i Arnarbælislandi i Ölvesi, par sem heita Nautaeyrar, pað er prír fjórðúngar bingmannaleiðar } \\
\text { til að sækja og er bó flæðiengi, so sæta parf sjáfarföllum pegar hey skal á hestum paðan færa, en verkamenn } \\
\text { í fári ef stórflæði tilfalla, so sem oft hefur að skaða orðið. Hjer í mót á staðurinn skipsstöðu fyrir } \\
\text { Porkelsgerði, vide Arnarbæli. } \\
\text { Porkelsgerði has access to Arnarbali’s meadows, in a place called Nautaeyrar, in a tidal zone, so that care } \\
\text { must be taken when bringing hay from there by horseback, or else the workers will be left moored by the } \\
\text { tide, which has often happened. In turn, Arnarbceli rows a single boat to sea on Porkelsgerði's shores. }\end{array}$ \\
\hline Porlákshöfn & Arnarbæli & hay & $\begin{array}{l}\text { Engjatak á jörðin á Arnarbælisengjum, og er pað kallað Tiuaura engi, aðrir nefna Stakksengi. Pað brúkar } \\
\text { Porlákshöfn árlega, en staðurinn Arnarbæli par í mót áttæríngs skipsstöðu í Porlákshöfn, og er ekki fyrir } \\
\text { goldið pó stærri skip gángi. } \\
\text { Porlákshöfn has access to Arnarbali’s meadows, called both Tiuaura meadow and Stakks meadow. } \\
\text { Dorlákshöfn uses it yearly, and in return Arnarbali rows to sea from Porlákshöfn's harbours. }\end{array}$ \\
\hline Porlákshöfn & Breiðabólsstaður & $\begin{array}{r}\text { shieling } \\
\text { place }\end{array}$ & $\begin{array}{l}\text { Skipsuppsátur á jörðin í Porlákshöfn fyrir selstöðu í heimalandi. } \\
\text { Breiðabólsstaður has a ship place in Porklákshöfn in exchange for a shieling place. }\end{array}$ \\
\hline
\end{tabular}

stewardships centred on Bessastaðir in the south and the preReformation properties of the monasteries, claimed by the Danish crown in the mid-sixteenth century (see Karlsson 2000). They operated both as the seat of their respective sees comprising over 2500 and 1500 farms respectively, as well as directly owning vast amounts of property (Hólar owned 344 properties in the early eighteenth century while Skálholt owned 309). Due to length considerations, I here present a 


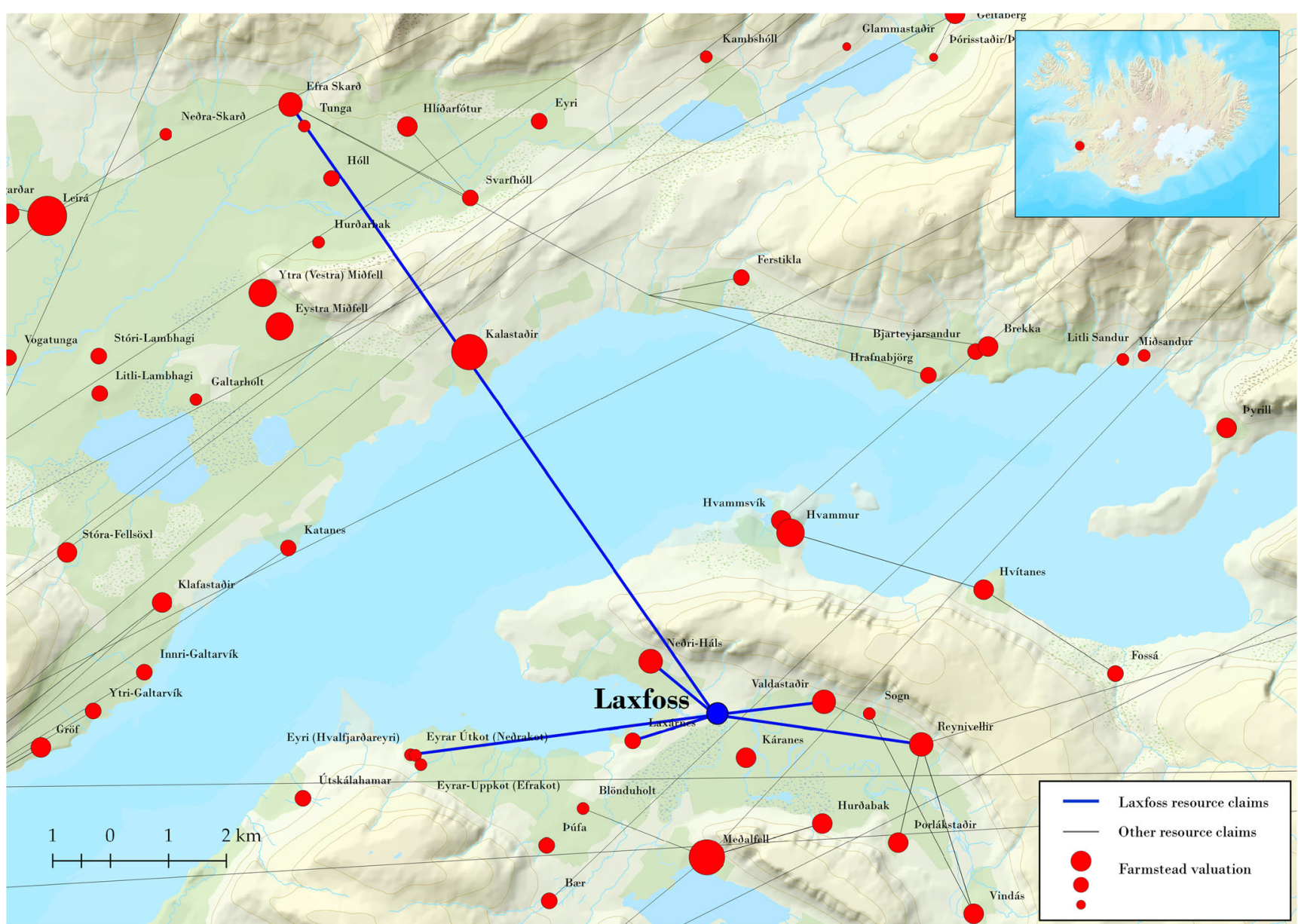

Fig. 8 Laxfoss and its claimants

brief summary of my current research on Skálholt from a systems perspective.

Skálholt was the spiritual and secular centre of roughly three quarters of the country, stretching clockwise from Langanes in the north east to Hrútafjörður in the north west. In addition to the vast amounts of rent and tithe that Skálholt generated from its parishioners and tenants, it played an important role in managing the wider landscape through a stewardship of resource claims. Skálholt had grazing rights for its animals on many of its nearby tenant farms and oversaw, through a network of bailiffs, the transport of driftwood from the shoreline to Skálholt to wherever the timber was needed (Grímsdóttir 2008).

Skálholt's tenants were also connected through resource claims. In addition to frequent instances of tenant farmers exchanging one resource for another - most often meadow access for pasture access - certain farms acted as suppliers of limited resources to nearby tenants. This was an arrangement that was, at times, to the detriment of the supplier farm itself. For instance, the census record for the tenant farms Fell and Efstidalur in Árnessýsla indicate that woodland was being over utilized for charcoal making by nearby tenant farmers whose access appears to be sanctioned by the bishopric
(Magnússon and Vídalín 1913-1943, II). Similar records suggest that resource access between tenant farmers regularly did not suit either party, often due to complicated logistics involved or to undue environmental pressures on fragile resources. These arrangements were arguably made to suit Skálholt's wider interests instead, dispersing resources across its properties which often required significant output of unpaid labour from its tenant farmers.

Examples from the northern bishop in Skagafjörður show that episcopal tenant farmers facing a shortage of a vital resource could approach the bishop to address this shortage, likely through his bailiffs. For instance, Hóll in Norður-bingeyjasýsla in the north east of the country harvested hay in Keldunes, which the census records indicate was rather hard for the tenants to access, but Keldunes was the closest farmstead also owned by Skálholt (Magnússon and Vídalín 1913-1943, XI: 36). Similarly, the tenant farm Hraun í Fljótum (Magnússon and Vídalín 1913-1943, IX: 339) did not have adequate turf. It did not trade with any of its neighbours, however. Instead, the tenants travelled south to Hamrar, which according to the text is an arduous journey that takes over a week every year. The reason for this unlikely source of turf is that the arrangement was been made by 


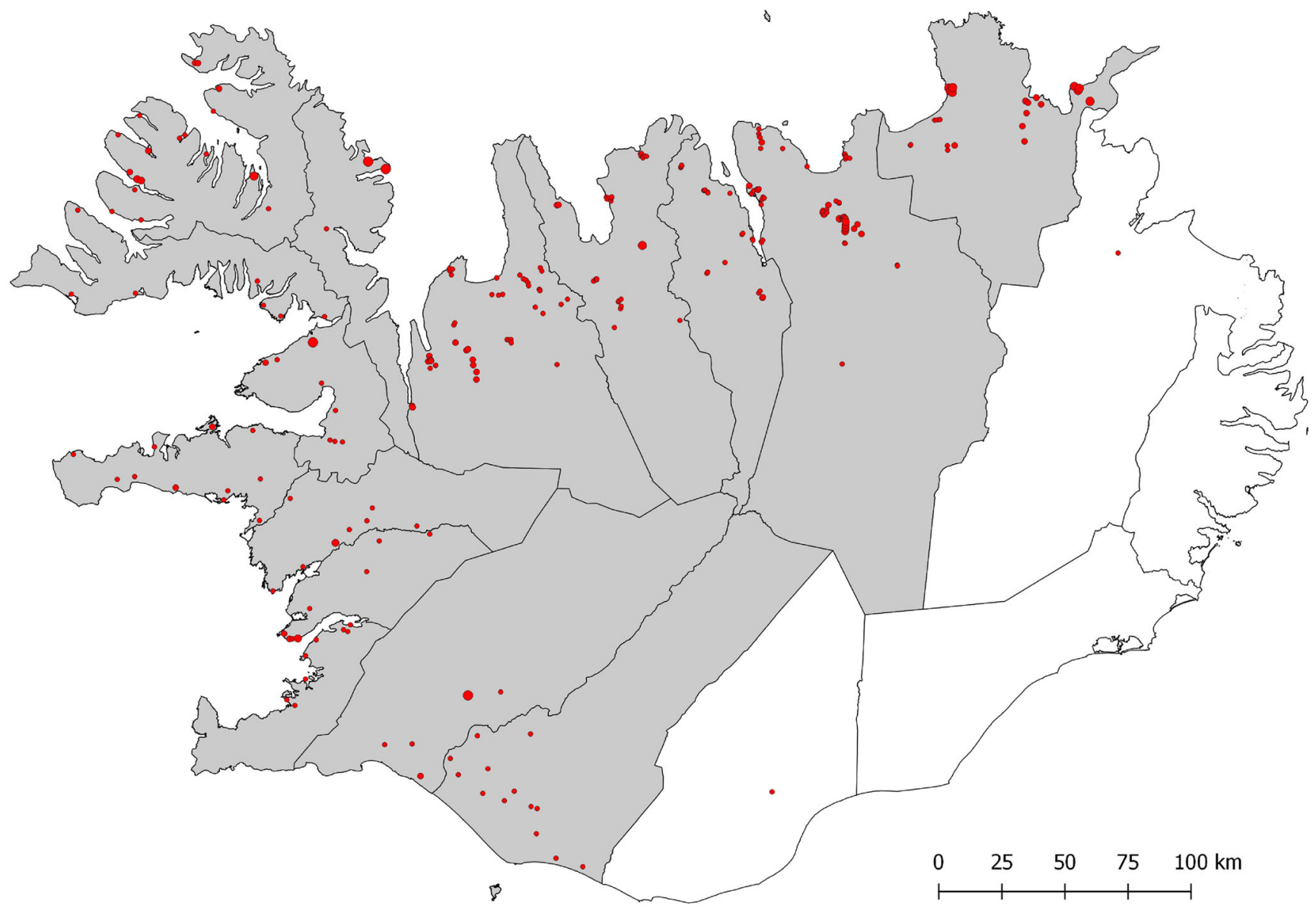

Fig. 9 Centres of claim assemblages

\section{Centre-oriented assemblages: central farmsteads and social status}

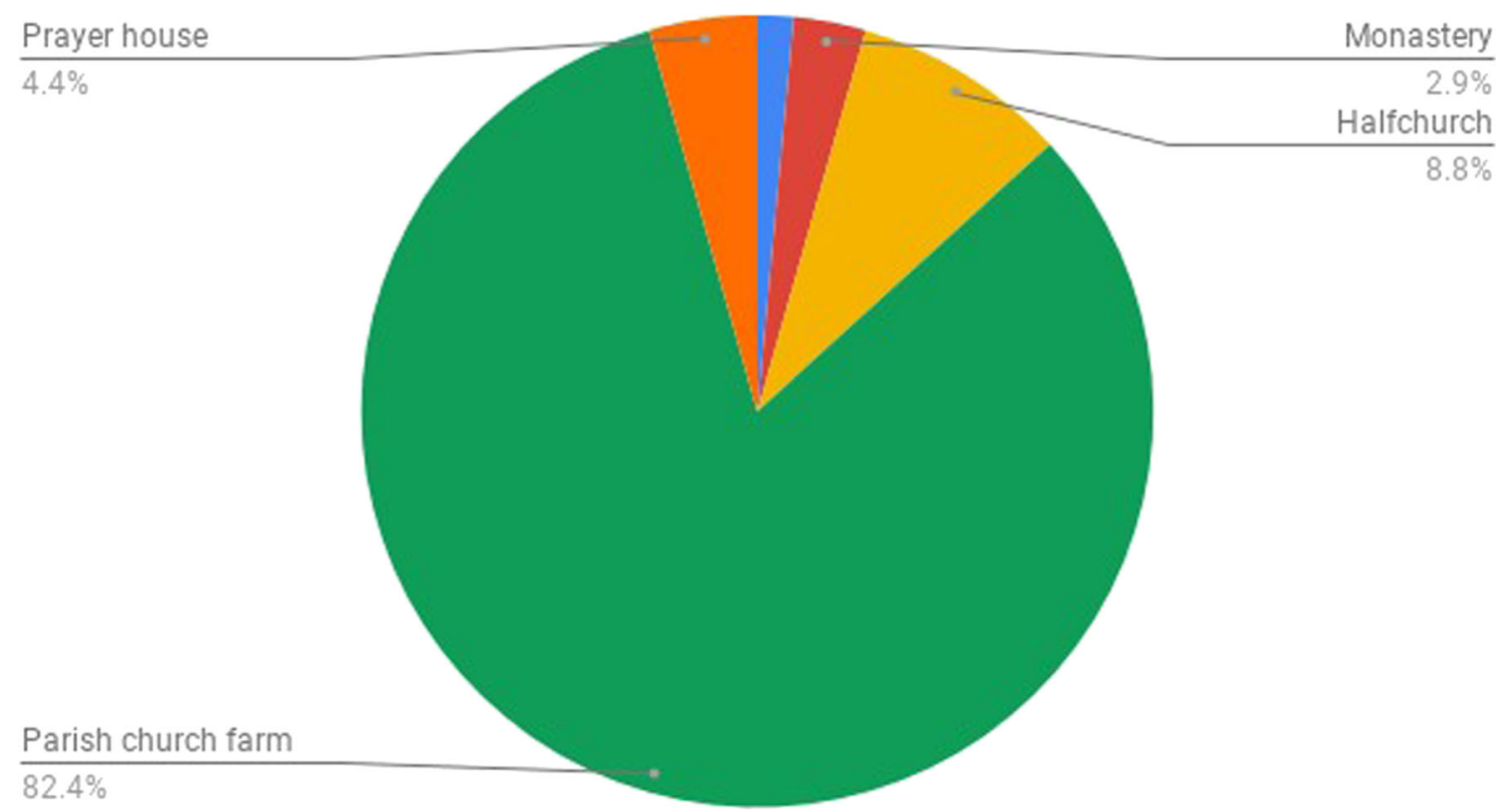

Fig. 10 Centres of claim assemblages ordered by ecclesiastical status. Less than $2 \%$ (shown in blue) had no ecclesiastical affiliation 


\section{Coupled subsistence, assemblages and semi-state systems} An enchainment of scales

\section{I: Coupled subsistence}

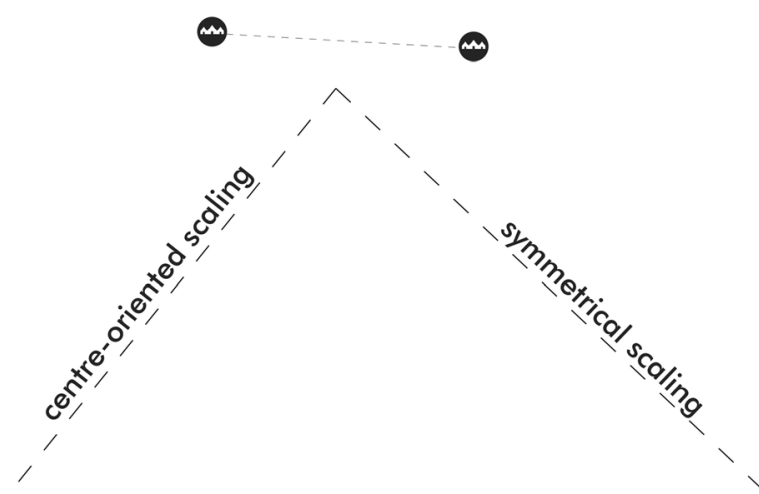

Ila: Centre-oriented assemblages (resource-centric or magnate-centric)
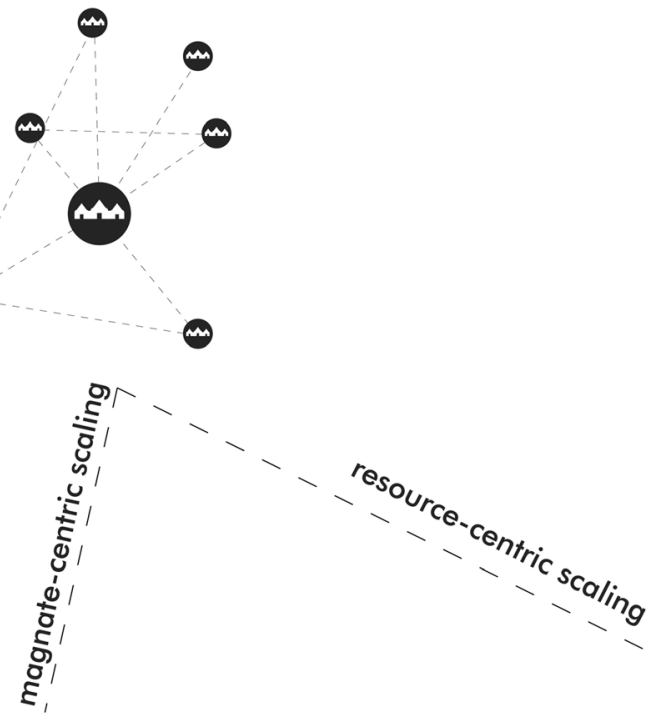

Illa: Semi-state systems

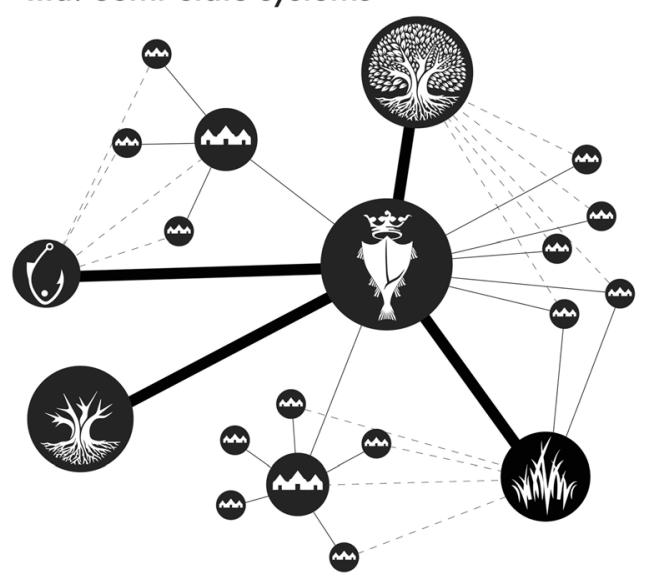

Ilb: Symmetrical assemblages

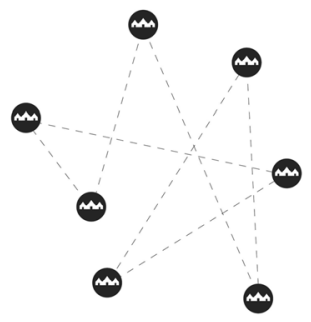

Fig. 11 The relationship between claim assemblages at different scales

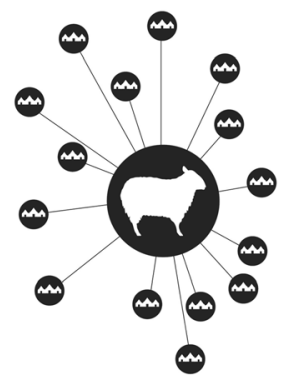


Hólar's bailiff in the region. It is likely that Hamrar was the closest farm owned by the bishop that had an abundance of turf. Whether or not that was the case, the broader point is that this particular arrangement did not arise from a logical interaction between neighbours, but from the decision-making of a regional power, most likely benefiting the entire assemblage of properties under the bishopric, even if it led to a particularly cumbersome arrangement for the tenants at Hraun.

\section{Discussion: An Enchainment of Scales}

\section{Ítak Categories Ordered to Micro, Meso, and Macro Scales}

I have presented the Icelandic itak as a series of overlapping networks, and shown that in the absence of a fixed, market infrastructure for domestic trade, farmers in eighteenth century Iceland relied on negotiated access to resources on other farms, in arrangements that often lasted generations. Eighteenth century Iceland was an agricultural society of individuated and dispersed farmsteads that were nevertheless highly interdependent. Taking a cue from Knappett (2013), I've ordered the itak categories suggested here according to three scales - the micro, meso, and macro (Fig. 11). I should emphasise that the phenomena at these different scales are by no means distinct or independent. As noted earlier, the simplest resource claim category - the coupled subsistence - is most commonly found as a feature of the semi-state systems managed by the two bishoprics and the Danish crown.

It is rather that these categories are enchained across scales. Site to site interaction through shared and claimed resources traverse the scales from binary engagements to large systems spanning the entire island. As farmsteads interact at ever larger scales, we see an emergence of mechanisms needed to effect material flows involving long distances and several agents. The fundamental role of the itak (pl. itök) remains relatively unchanged, however. It is just that as resource claims articulate at ever greater scales, they begin to show more complex forms. These three scales are enchained, as any given resource claim interaction may be influenced by patterns taking place at other scales. Moreover, these resource claims are highly dependent on other site to site interactions - property networks, community networks, trade networks, and so on. For that reason, the resource claim networks cannot be fully understood without reference to other socio-dynamics. But by focusing on one dimension of connectivity it is possible to begin to build toward an interpretation of a farmstead site with full awareness of its high degree of connectivity, and to move, step by step, toward a release from proximity.
Acknowledgements I am grateful to several colleagues at Umeå University, the North Atlantic Biocultural Organization, and Fornleifastofnun Íslands for productive discussions through the years. I especially thank Gavin Lucs, Orri Vésteinsson, Oscar Aldred, Howell Roberts, Adolf Friðriksson, Birna Lárusdóttir, Phil Buckland, Doug Bolender, Elín Hreiðarsdóttir, Emily Lethbridge Rachel Opitz, Árni Daníel Júlíusson, Tom McGovern, Colleen Strawhacker, and Megan Hicks. I would also like to thank the two anonymous reviewers for very helpful comments.

Funding Information Open access funding provided by Umea University. This work was carried out in collaboration with the DataArc project. DataArc is supported by the National Science Foundation, Grant Numbers 1637076 and 1439389.

\section{Compliance with Ethical Standards}

Conflict of Interest The author declares that he has no conflicts of interest.

Ethical Approval This article does not contain any studies with human participants or animals.

Informed Consent Informed consent was obtained from all individual participants included in the study.

Open Access This article is distributed under the terms of the Creative Commons Attribution 4.0 International License (http:// creativecommons.org/licenses/by/4.0/), which permits unrestricted use, distribution, and reproduction in any medium, provided you give appropriate credit to the original author(s) and the source, provide a link to the Creative Commons license, and indicate if changes were made.

\section{References}

Ágústsson, H. (1998). Íslensk byggingararfleifð, Húsafriðunarnefnd ríkisins, Reykjavík?

Amorosi, T., Buckland, P., Dugmore, A., Ingimundarson, J. H., and McGovern, T. H. (1997). Raiding the Landscape: Human Impact in the Scandinavian North Atlantic. Human Ecology 25(3): 491518.

Brughmans, T. (2013). Thinking Through Networks: A Review of Formal Network Methods in Archaeology. Journal of Archaeological Method \& Theory 20: 623-662.

Buckland, P. C., Dugmore, A. J., Perry, D. W., Savory, D., and Sveinbjarnardóttir, G. (1991). Holt in Eyjafjallasveit, Iceland. A palaeoecological Study of the Impact of Landnám. Acta Archaeologica 61(1990): 252-271.

Eggertsson, Ó. (1993). Origin of the Driftwood on the Coasts of Iceland: A Dendrochronological Study. Jokull 43: 15-32.

Graeber, D. (2011). Debt : The First 5,000 Years, Melville House, Brooklyn.

Grímsdóttir, G. Á. (2008). Biskupsstóll í Skálholti. In Kristjánsson, G. (ed.), Saga Biskupsstólanna, Bókaútgáfan Hólar, Reykjavík, pp. 21 428.

Guðmundsson, G. F. (1993). Jarðabréf frá 16. og 17. öld: útdrættir. Copenhagen: hið íslenska fræðafélag í Kaupmannahöfn.

Gunnarsson, G. (1987). Upp er boðið Ísaland: einokunarverslun og íslenskt samfélag 1602-1787. Reykjavík: Örn og Örlygur.

Karlsson, G. (2000). Iceland's 1100 Years : The History of a Marginal Society. Reykjavík: Mál og Menning. 
Karlsson, G., Árnason, M., \& Sveinsson, K. (1992). Grágás: lagasafn íslenska pjóðveldisins. Reykjavík: Mál og Menning.

Knappett, C. (Ed.) (2013). Network Analysis in Archaeology. Oxford: Oxford University Press.

Kristjánsson, L. (1980). Íslenzkir sjávarhættir 1, Bókmenntaútgáfa menningarsjóðs, Reykjavík.

Magnússon, Á. (1916). Embedsskrivelser og andre offenlige aktstykker, utgivet af Kr. Kålund, Gyldendal, Copenhagen.

Magnússon, Á., and Vídalín, P. (1913-1943). Jarðabók Árna Magnússonar og Páls Vídalín, Hið íslenzka fræðafjelag, Copenhagen.

McGovern, T. H., Vesteinsson, O., Fridriksson, A., Church, M., Lawson, I., Simpson, I. A., et al (2007). Landscapes of Settlement in Northern Iceland: Historical Ecology of Human Impact and Climate Fluctuation on the Millennial Scale. American Anthropologist 109(1): 27-51.

Mehler, N. (2015). Bingvellir: A Place of Assembly and a Market? Journal of the North Atlantic 8: 69-81.

Mooney, D. E. (2018). Charred fucus-type seaweed in the North Atlantic: A survey of finds and potential uses. Paper presented at the Expanding Horizons, Modalen, Norway.

Ólafsson, E., \& Pálsson, B. (1974). Ferðabók Eggerts Ólafssonar og Bjarna Pálssonar um ferðir peirra á Íslandi árin 1752-1757. Reykjavík: Örn og Örlygur.

Ostrom, E. (1990). Governing the Commons : The Evolution of Institutions for Collective Action, Cambridge University Press, Cambridge ; New York.
Pálsson, G. (2018). Storied Lines: Network Perspectives on Land Use in Early Modern Iceland. Norwegian Archaeological Review 51(1-2): $1-30$.

Smith, K. (1995). Landnam: The Settlement of Iceland in Archaeological and Historical Perspective. World Archaeology 26(3): 319-347.

Stefánsson, H. (2013). Af jörðu, Crymogea, Reykjavík.

Steindórsson, S. (1948). Akuryrkja á Íslandi í fornöld og fyrr á öldum.

Pórhallsdóttir, P. E. (2001). Ásýnd landsins. Fræðaping Landbúnaðarins 2001: 77-85.

Vésteinsson, O. (2006). Communities of Dispersed Settlements: Social Organization at the Ground Level in Tenth-to Thirteenth-Century Iceland People and Space in the Middle Ages, 300-1300 (pp. 87113). Turnhout: Brepols.

Vésteinsson, O., and McGovern, T. H. (2012). The Peopling of Iceland. Norwegian Archaeological Review 45(2): 206-218.

Vésteinsson, O., McGovern, T., and Keller, C. (2002). Enduring Impacts: Social and Environmental Aspects of Viking Age Settlement in Iceland and Greenland. Archaeologica Islandica 2: 98-136.

Publisher's Note Springer Nature remains neutral with regard to jurisdictional claims in published maps and institutional affiliations. 